\title{
IAMJ
}

INTERNATIONAL

AYURVEDIC

MEDICAL JOURNAL

\section{A CLINICAL STUDY TO EVALUATE THE EFFECT OF GUDUCHYADI SYRUP IN ENHANCEMENT OF MEDHA IN SCHOOL GOING CHILDREN}

\author{
Navya. N. $P^{1}$, Sharada. M. K ${ }^{2}$, Jithesh Chowta $^{3}$ \\ ${ }^{1}$ PG Scholar, Dept. of PG studies, Kaumarabhritya, Alva's Ayurveda, Medical College, Moodbidri, Mangalore, \\ Karnataka, India \\ ${ }^{2}$ Professor, Dept. of PG studies, Kaumarabhritya, Alva's Ayurveda, Medical College, Moodbidri, Mangalore, \\ Karnataka, India \\ ${ }^{3}$ Assistant Professor, Dept. of PG Studies, Kaumarabhritya, Alva's Ayurveda, Medical College, Moodbidri, \\ Mangalore, Karnataka, India
}

Corresponding Author: drnavyanp777@gmail.com

\section{https://doi.org/10.46607/iamj1108092020}

(Published online: September 2020)

Open Access

(C) International Ayurvedic Medical Journal, India 2020

Article Received: 23/08/2020 - Peer Reviewed: 01/09/2020 - Accepted for Publication: 02/09/2020

Check for updates

\section{ABSTRACT}

Academic underachievement of children is a big concern among parents and teachers in present day competitive society. It is reported that around $20 \%$ of school children have scholastic backwardness include physical illness, below average Intelligence, Learning Disabilities, Attention Deficit Hyperactive Disorder, Psychiatric Disorder, family and school factors. Intelligence is usually said to involve mental capabilities such as the ability to reason, plan, solve problems, think abstractly, comprehend ideas and language, and learn. In spite of advancement in modern medicine, its success is very limited in context with the enhancement of Intellectual power and memory. Objectives: 1) To select subject with IQ ranging from 70 - 89 and study in detail about the factors influencing the Intelligence. 2) To evaluate the effect of Guduchyadi Syrup in the enhancement of Medha in school going children.

Materials and Methods: An interventional Randomized Placebo Controlled Clinical study was conducted, in which 30 subjects were assigned in both Group A and Group B and given with Guduchyadi syrup and Sugar 
syrup respectively, with a dose of $5 \mathrm{ml}$ thrice a day after food for duration of 3 months. Follow up was done on $30^{\text {th }}$ day after completion of the treatment.

Interpretation and Result: Both the groups showed significant result in Subjective and Objective parameters. Conclusion: Both Guduchyadi syrup and Sugar syrup are having significant effect on Medha. The effect is considered to be consistent or improved even after follow up. But the change was less for the group given with Sugar syrup compared to the effect of Guduchyadi syrup.

Keywords: Medhya, Intelligence, Intelligence Quotient, Guduchyadi syrup, Sugar syrup

\section{INTRODUCTION}

In Ayurvedic classics 'Medha' has been defined as main as unobstructed and uninterrupted perception and retention of the knowledge in all the aspects of an object. Besides this, Buddhi, Smriti, Dhi etc. are different entities used to mention different aspects of Medha. For the cognition of sense, objects conjoin with senses and senses with Manas. Buddhi Vyapara (discrimination) follows just after it. Buddhi works on it by reasoning and logic and reacts accordingly. Finally, the gained knowledge gets stored for further use. Retention of cognition takes place under the area of Medha. When any stimulant comes against, those stored experience comes in mind, recollection happens, which is the area of Smriti. If the knowledge or experiences are not encoded and retained properly then all the efforts of recalling would be in vain. Thus, the process of recollection takes place properly only after the Buddhi Medha and Smriti unite. In this process Buddhi helps in encoding; Medha in retention and Smriti facilitate recollection ${ }^{1}$.

Intellectual ability is a complex phenomenon, influenced by factors both environmental and biological. In broad sense, intelligence is what people use to learn, remember, solve problems and in general, deal effectively with the world around them. Decreased intelligence may occur due to any Genetic, physical or psychological reason, or may be due to adverse environment for the development. Decrease in Intelligence level may limit an individual in areas such as learning, reasoning, communication and selfhelp skills. There are a number of different methods which to measure intelligence, the most famous of which is the "I.Q." or 'Intelligence Quotient' test ${ }^{2}$. A specific intervention may contribute to better performance in school. Medhya Rasayana, the group of drugs explained in Ayurvedic classics are considered to be having immense action on the Medha. Guduchyadi rasayana is one such formulation explained in Bhaishajya Ratnavali Rasayanaadhikara. ${ }^{3}$ In this study an attempt was made to evaluate the Medhya effect of Guduchyadi Rasayana which was modified as Syrup form for the convenience of the subjects.

\section{Objectives}

1. To select subject with IQ ranging from $70-89$ and study in detail about the factors influencing the Intelligence.

2. To evaluate the effect of Guduchyadi Syrup in enhancement of Medha in school going children.

\section{Materials \& Methods}

\section{Source of Data:}

Literary source: Textbooks of Ayurvedic and Modern medicine, journals, articles and information from reliable internet sources, about the disease and the drugs were reviewed.

Sample Source: Subjects were selected randomly from High Schools in and around Moodbidri, special medical camps and other sources.

Drug Source: Raw drugs were collected from the available local market and the syrup was prepared in the Rasa Sastra and Bhaishajya Kalpana Lab, Alva's Ayurveda Medical College, Moodbidri.

\section{Method of Preparation:}

Guduchyadi Syrup: All drugs were taken in equal quantity and cleaned in running water to remove dirt and later dried and then made into coarse powder and mixed together and added with 16 times water and boiled and reduced to 1/8 to prepare Kashaya and was 
sieved and collected in a vessel and heated. $35 \%$ of Sugar was added to the Kashaya and heated till it attains one thread consistency. The syrup prepared was kept for self cooling to normal temperature. Later it was collected in $100 \mathrm{ml}$ bottles.

Sugar Syrup: Quantity sufficient water was taken and kept for boiling. 35\% of sugar was added to it and stirred well and heated until the one thread consistency was attained. The sugar syrup was kept for self cooling and later collected in $100 \mathrm{ml}$ bottles.

\section{Method Of Collection Of Data:}

Study Design: A Randomized Placebo - Controlled clinical study.

\section{Sampling Method:}

Random sampling method: Subjects Fulfilling the Diagnostic and Inclusion criteria were selected by conducting screening camp at Schools in and around Moodbidri. The samples were selected by giving equal and independent chances of selection to each and every children of the population between 13 to 15 yrs of age. Subjects were selected in Simple Random method and assigned in to two groups, Group A (Trail) and Group B (Control).

Sample Size: 65 subjects

\section{Selection Criteria:}

Diagnostic Criteria: Diagnosis was made using Wechsler Intelligence Scale (Malin's Intelligence Scale for Indian Children). Students with IQ Score ranging from $70-89$ were selected for the study.

Inclusion Criteria:

1. Students with IQ between 70 - 89

2. Age group of 13 to 15 yrs.

3. Students of either Gender.

\section{Exclusion Criteria:}

1. Children with Learning Disability, Mental Retardation, and Attention Deficit Hyperactive Disorder.

2. Children with other Developmental disorders.

3. Children suffering from any Systemic disorders.

Procedure of Administration of the Drug:

Group A - Trial group was given with Guduchyadi Syrup.

Group B - Control group was given with Sugar syrup.

\section{Mode of Administration: Orally}

Dose: $5 \mathrm{ml}$ trice a day after food for all subjects irrespective of Age.

Duration: 3 Months.

\section{Observation Period:}

- Treatment duration: 90 days

- Assessment of subjects was done BT, on $45^{\text {th }}$, and $90^{\text {th }}$ day.

- Follow up period: Follow up study will be done on $30^{\text {th }}$ day after completion of the treatment.

- Total study duration including follow up: 120 days.

\section{Assessment Criteria:}

The Assessment parameters used for the study include:

$>$ Medha Grahanena

$>$ Smriti Smaranena

$>$ Dhritii Alaulyena

$>$ Vijnanam Vyavasayena

$>$ Indian adaptation of Wechsler Intelligence scale for Children. (Malin's Intelligence Scale for Indian School Children) was adopted to assess the IQ before and after the treatment.

Table 1: Grading of Medha:

\begin{tabular}{|l|l|}
\hline Medham Grahanena & Score \\
\hline Can grasp the event at an instance, no confusional status & 3 \\
\hline Can grasp the events at an instance, but get confused & 2 \\
\hline Delayed grasping with frequent confusion & 1 \\
\hline Grasping and understanding is difficult with lack of confusion & 0 \\
\hline
\end{tabular}


Table 2: Grading of Smriti:

Smritim Smaranena

Both remote and recent memory are clear with easy retention and recall

Both remote \& recent memory clear, but retention and recall are not seen

Remote memory is impaired, but recent memory is intact. Power of retention and recall not seen

Both remote and recent memories are impaired, difficult retention $\&$ recall.

\begin{tabular}{|l|}
\hline Score \\
\hline 3 \\
\hline 2 \\
\hline 1 \\
0
\end{tabular}

Table 3: Grading of Dhriti:

Dhritim Alaulyena Score

Courageous on all occasions 3

Courageous if supports are there

Occasionally courageous if strong support is there

No change at all

2

1

0

Table 4: Grading of Vijnana:

Vijnanam Vyavasayena Score

Self-efficient and sufficient to direct and do various activities himself.

3

Self efficient and sufficient and do various activities with help of others.

3

Not self efficient and sufficient, guidance required in each and every work

Cannot do or direct any activity with loss of insight.

2

1

Malin's Intelligence Scale for Indian Children - MISIC

(Indian adaptation of Wechsler Intelligence Scale for Children.)

This includes:

Verbal

Performance

1. Information 7. Picture Completion

2. Comprehension 8. Picture Arrangement

3. Arithmetic 9. Block Design

4. Similarities 10. Object Assembly

5. Vocabulary 11. Coding

6. Digit span 12. Mazes

Gradation of IQ Scores: IQ test results were distributed according to the following classification

given by NIMH (National Institute of Mental Health, Bangalore.)

\section{Results:}

Table 5: Result of statistical analysis in both the groups and between the groups:

Parameters

\begin{tabular}{|l|l|l|l|}
\hline Parameters & p value & Group B & Between Groups \\
\hline Medha & Group A & $0.003(\mathrm{~S})$ & 0.453 \\
\hline Smriti & 0.016 (S) & $<0.001$ (HS) & $<0.001$ (HS) \\
\hline Dhriti & $<0.001$ (HS) & $0.002(\mathrm{~S})$ & $<0.001$ (HS) \\
\hline Vijnana & $<0.001$ (HS) & $0.032(\mathrm{~S})$ & $0.012(\mathrm{~S})$ \\
\hline Verbal IQ & $<0.001$ (HS) & $<0.001(\mathrm{HS})$ & $0.002(\mathrm{~S})$ \\
\hline Performance IQ & $<0.001$ (HS) & $<0.001$ (HS) & 0.170 (NS) \\
\hline Total IQ & $<0.001$ (HS) & $<0.001(\mathrm{HS})$ & 0.003 (S) \\
\hline
\end{tabular}


Table 6: Percentage of improvement in group A and group B:

\begin{tabular}{|c|c|c|c|c|c|c|}
\hline \multirow{3}{*}{$\begin{array}{l}\text { Characteristics } \\
\text { Parameters }\end{array}$} & \multicolumn{3}{|c|}{ Group A } & \multicolumn{3}{|c|}{ Group B } \\
\hline & \multicolumn{2}{|c|}{ Mean Score } & \multirow[t]{2}{*}{$\%$} & \multicolumn{2}{|c|}{ Mean Score } & \multirow[t]{2}{*}{$\%$} \\
\hline & BT & AT & & BT & AT & \\
\hline Medham Grahanena & 1.333 & 1.733 & $23.08 \%$ & 1.233 & 1.5 & $17.8 \%$ \\
\hline Smritim Smaranena & 0.666 & 1.966 & $66.12 \%$ & 1.166 & 1.566 & $25.54 \%$ \\
\hline Dhriti Alaulyena & 1 & 2.133 & $53.11 \%$ & 1.266 & 1.6 & $20.87 \%$ \\
\hline Vijnanam Vyavasayena & 0.733 & 1.433 & $48.84 \%$ & 0.966 & 1.2 & $19.5 \%$ \\
\hline Verbal IQ & 82.833 & 101.1 & $18.06 \%$ & 85.593 & 94.166 & $9.10 \%$ \\
\hline Performance IQ & 85.233 & 95.786 & $11.01 \%$ & 88.64 & 96.336 & $7.98 \%$ \\
\hline Total IQ & 83.966 & 98.466 & $14.72 \%$ & 87.03 & 94.97 & $8.36 \%$ \\
\hline \multicolumn{3}{|c|}{ Average $\%$ of Improvement } & $33.56 \%$ & & & $15.59 \%$ \\
\hline
\end{tabular}

Percentage of improvement on Medha is $23.08 \%$, Smriti is $66.12 \%$, Dhriti is $53.11 \%$, Vijnana is $48.84 \%$, verbal IQ is $18.06 \%$, performance IQ is $11.01 \%$ and total IQ is $14.72 \%$. Percentage of improvement on Medha is $17.8 \%$, Smriti is $25.54 \%$,
Dhriti is $20.87 \%$, Vijnana is $19.5 \%$, verbal IQ is $9.10 \%$, performance IQ is $7.98 \%$ and total IQ is $8.36 \%$. Average percentage of improvement in Group $\mathrm{A}$ is $33.56 \%$ and in Group B is $15.59 \%$.

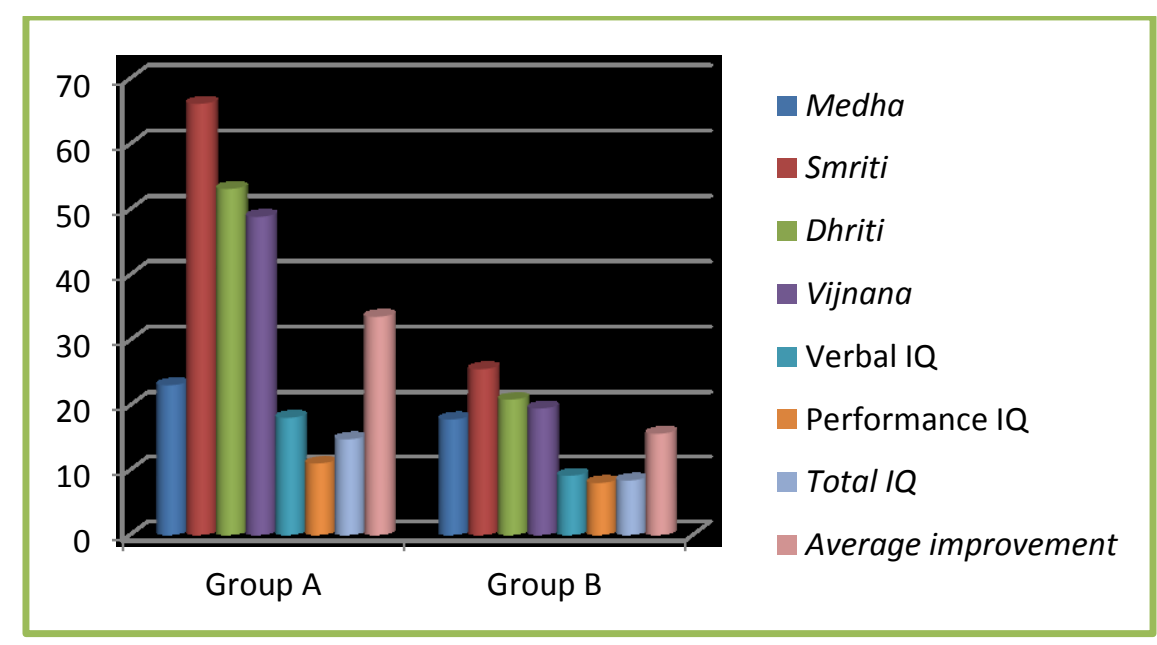

\section{DISCUSSION}

Probable mode of Action of Guduchyadi syrup: All the drugs are having Tikta Rasa predominantly. Apamarga, Vidanga and Vacha are having Katu Rasa along with Tikta. Other than Tikta Rasa, Guduchi is having Kashaya Rasa, Kushta is having Madhura and Katu Rasa and Shatavari is having Madhura Rasa. Haritaki is having Pancharasa with Kashaya as Pradhana Rasa. Sharkara which is Madhura Rasa Pradhana. Almost all the drugs are Ruksha, Laghu and Tikshna; few are Guru and Snigdha. All drugs are having Ushna Virya other than Shankhapushpi,
Shatavari and Sharkara. Among the 9 ingredients, five are having Madhura Vipaka and four are having Katu Vipaka. Shankhapushpi and Vacha are having Prabhava as Medhya. Guduchi, Shankhapushpi and Haritaki are Tridosha Shamaka and remaining drugs are predominantly Kapha Vata Shamaka.

Almost all drugs are having Pachana and Deepana property which acts on Koshta level and helps for Srotoshodhana. All drugs are having Rasayana effect on body and are considered to be having direct action on Medha. Rasayana acts at the level of Agni, Dhatu and Srotas. As the functions of Sharira and Manas are 
interrelated proper functioning of whole body is important to develop the Buddhi, Medha etc. While considering Medhya Rasayana it also acts on body same as any of the Rasayana.

- Agni - Proper functioning of Jataragni, Dhatvagni, Bhutagni are important for proper functioning of Dosha, Dhatu, Indriya and Manas. Bhutagni helps for nourishment of Indriyas.

- Dhatu - Rasaraktadi Dhatus which are getting Poshana is important for the functioning of Hrudaya and Mastishka.

- Srotas: Sharira Srotas as well as Manovaha Srotas which are healthy will nourish Dhatu and Indriyas and hence results in proper perception of Knowledge.

Medhya Rasayana act at different levels based on Rasa Panchaka, i.e.

- Sita Virya and Madhura Vipaka - promotes Dharana Karma.

- Ushnavirya, Tiktarasa - Promotes Sadhaka Pitta which act on Buddhi, Medha, Grahana and Smarana and also improves Pachakagni.

- Tikta Rasa - Due to Akasha and Vayu Mahabhuta predominance, cause Srotovishodhana by which acts on Medha.

- Sita Virya, Madhura, Tikta, Kashaya Rasa Indriya Prasadana and helps in Vishayagrahana and Ekagrata of Manas.

- Ushna Virya, Laghu, Tikshna, Ruksha Guna removes the obstruction by Kapha or Tamoguna in Manovaha Srotas.

- Ushna virya - promotes Sadhaka Pitta which is responsible for proper Buddhi and Medha and also eliminates Kapha and Tamas from Hrudaya.

- Madhura Rasa is having Sarvendriya Prasadaka property, which helps for Jnanaprapti. ${ }^{4,5}$

\section{Probable mode of action of Placebo:}

- Placebo effect involves a complex neurobiological reaction that includes everything from increase in feel good neurotransmitters, like Endorphin and dopamine, to greater activity in certain brain regions linked to moods, emotional reactions and self - awareness. All of it can give therapeutic benefit.
- Environmental and psychosocial factors are said to influence placebo effects are verbal suggestions, expectations, conditioning reward, reduction of anxiety and behaviors and attitudes manifested by health care providers

- Better response is seen in children compared to adults because the children's dependence on and trust in adults may render them particularly receptive to the doctor's assurance, encouragement and positive prognosis - elements of the treatment situation that contribute substantially to the placebo group. ${ }^{6}$

\section{CONCLUSION}

Based on the statistical study, it can be concluded that Guduchyadi syrup is having significant effect on medha (23.08\%) and highly significant effect on Smriti (66.12\%), Dhriti (53.11\%), Vijnana (48.84\%), Verbal IQ (18.06\%), Performance (11.1\%) and Total IQ (14.72\%). The main action of Guduchyadi syrup is at the level of Sadhaka Pitta which influences the Buddhi and Medha. It also possesses Agnivardhaka, Dhatuposhaka and Srotoshodhaka properties. After analyzing the data, it can be concluded that the effect of Guduchyadi syrup is statistically highly significant with a $p$ value $<0.001$ and there is a significant percentage of improvement, which is on the higher side compared to placebo effect.

\section{REFERENCES}

1. Ashalatha M, Kuber Sankh. Concept of Buddhi in Ayurveda: A review. J Pharm Sci Innov. 2014 ; 3 (6): Page no.499-503 http://dx.doi.org/10.7897/2277$\underline{4572.036204}$ )

2. H. R. Pal, A. Pal, P. Tourani, Theories of intelligence. everyman's science. Vol 39 no.3, august - September 2004. Page no.180.

3. Siddhi Nandan Misra, Bhaishajya Ratnavali, Kaviraj Govind Das Sen, Chaukamba Surbharati Prakasan, 2015, Page no.1109

4. D. S. Lucas, Dravyagunavijnana - Study of Dravya vol 2 Materia medica Chaulkamba Vushvabharati Publications, Varanasi, 2013. Page No.12

5. J. L. N. Sastry Illustrated Dravyaguna Vijnana (Study of the essential medical Plants in Ayurveda) Vol II, 
Chaukamba Orientalia, Varanasi, First edition 2004

Page No.35

6. Ulrike Bingel, Luana Colleca. Mechanism of Clinical Implication of the placebo effect. Gerontology.2010 Oct 26.

\section{Source of Support: Nil}

\section{Conflict of Interest: None Declared}

How to cite this URL: Navya. N. P et al: A Clinical Study To Evaluate The Effect Of Guduchyadi Syrup In Enhancement Of Medha In School Going Children. International Ayurvedic Medical Journal \{online\} 2020 \{cited September, 2020\} Available from:

http://www.iamj.in/posts/images/upload/4368_4374.pdf 